\title{
Activity of Fennel Fruit Extract (Foeniculum Vulgare Mill.) on Uterine of Immature Wistar Female Rat
}

\author{
(Aktivitas Ekstrak Buah Adas (Foeniculum Vulgare Mill.) \\ terhadap Uterin Tikus Wistar Betina yang Belum Dewasa)
}

\author{
KURNIA AGUSTINI ${ }^{1 *}$, DWI RIANI WULANDARI², LESTARI RAHAYU² \\ ${ }^{1}$ Center for Pharmaceuticals and Medical Technology \\ Laboratory for Development of Industrial Agro and Biomedical Technology \\ Agency for the Assessment and Application of Technology (BPPT). \\ ${ }^{2}$ Faculty of Pharmacy, University of Pancasila.
}

Diterima, 15 Maret 2017, Disetujui 8 Juli 2017

\begin{abstract}
Fennel fruit (Foeniculum vulgare Mill.) is one of traditional plant medicine known having effects as anti-inflammatory, analgesic and antioxidant. It also has been reputed to increase milk secretion, promote menstruation, facilitate birth, alleviates the symptoms of the male climacteric and increase libido. Fennel fruit contains mainly with essential oils, such as anethole. It also contains lignan and flavonoids that are predicted having an estrogen-like effect or as phytoestrogen. Phytoestrogen is weak agonists for estrogen and can elicit statistic significantly increases in uterine wet weight, at definite dose, in the uterothrophic bioassay. It is known that estrogen has effect on woman's sexual organ, such as proliferation of uterine, mammary and ovary. The aim of this research was to investigate the estrogenic effect of fennel fruit's ethanolic extract in immature, 19 days old, Wistar female rats. These models represent the climacteric/menopause phase, where estrogen level is very low because in this age, estrogen not yet produced by ovary. The testing animals were divided into five groups, namely normal group, estradiol control group and three level doses of fennel extract $(30 \mathrm{mg} / 200 \mathrm{~g} \mathrm{BW}$; $60 \mathrm{mg} / 200 \mathrm{~g} \mathrm{BW}$ and $120 \mathrm{mg} / 200 \mathrm{~g} \mathrm{BW})$. The result indicated that start on $60 \mathrm{mg} / 200 \mathrm{~g} \mathrm{BW}$, fennel extract significantly $(\alpha=0.05)$ increased wet weight of uterine. Fennel extract also lengthen the uterine and increased proliferation of uterine, such as uterine diameters, endometrium diameters and uterine thickness on dose $60 \mathrm{mg} / 200 \mathrm{gBW}$ and $120 \mathrm{mg} / 200 \mathrm{gBW}$. Analysis of vaginal smear showed vaginal lubrication effect, surprisingly start on $60 \mathrm{mg} / 200 \mathrm{BW}$ could induce estrous cycle.
\end{abstract}

Keywords: Fennel fruit, phytoestrogen, immature rat, Foeniculum vulgare Mill.

Abstrak: Buah adas (Foeniculum vulgare Mill.) merupakan salah satu tanaman obat tradisional yang dikenal memiliki efek sebagai anti-inflamasi, analgesik dan antioksidan. Dikenal juga untuk meningkatkan sekresi susu, mempromosikan menstruasi, memfasilitasi kelahiran, meringankan gejala klimakterik laki-laki dan meningkatkan libido. Buah adas banyak mengandung minyak esensial, seperti anethole, serta mengandung lignan dan flavonoid yang diprediksi memiliki efek seperti estrogen atau sebagai fitoestrogen. Fitoestrogen adalah agonis lemah untuk estrogen dan dapat menimbulkan peningkatan yang signifikan dalam berat basah uterus, pada dosis tertentu, dalam bioassay uterothrophic. Telah diketahui bahwa estrogen memiliki efek pada organ seksual wanita, seperti proliferasi uterus, kelenjar susu dan ovarium. Tujuan dari penelitian ini adalah untuk menyelidiki efek estrogenik ekstrak etanol buah adas pada tikus Wistar yang belum dewasa berusia 19 hari. Model-model ini mewakili fase klimakterik / menopause, di mana tingkat estrogen sangat rendah karena pada usia ini, estrogen belum diproduksi oleh ovarium. Hewan uji dibagi menjadi lima kelompok, yaitu kelompok normal, kelompok kontrol estradiol dan tiga tingkat dosis ekstrak adas $(30 \mathrm{mg} / 200 \mathrm{~g} \mathrm{BB} ; 60 \mathrm{mg} / 200 \mathrm{~g}$ BB dan $120 \mathrm{mg} / 200$ $\mathrm{g}$ BB). Hasilnya menunjukkan bahwa mulai dari $60 \mathrm{mg} / 200 \mathrm{~g} \mathrm{BB}$, ekstrak adas secara signifikan $(\alpha=$ $0,05)$ meningkatkan berat basah uterus. Ekstrak adas juga memperpanjang uterus dan meningkatkan proliferasi uterin, seperti diameter uterus, diameter endometrium dan ketebalan uterus pada dosis $60 \mathrm{mg}$ / 200gBW dan $120 \mathrm{mg} / 200 \mathrm{gBB}$. Analisis pulasan cairan vagina menunjukkan efek lubrikasi vagina, secara mengejutkan dimulai pada $60 \mathrm{mg} / 200 \mathrm{~g}$ BB dapat menginduksi siklus estrus.

Kata kunci: Buah adas, fitoestrogen, tikus belum dewasa, Foeniculum vulgare Mill.

\footnotetext{
* Penulis korespondensi, Hp 081386583899

e-mail: kurnia.agustini@bppt.go.id
} 


\section{INTRODUCTION}

FENNEL, Foeniculum vulgare Mill., is a herb of the carrot family, which have aromatic seeds for both culinary and herbal uses, usually used at the end of a meal in Asia and in South America to sweeten the breath and aid digestion. For centuries, fennel fruits have been used as traditional herbal medicine in Europe and China. Fennel tea is the herb of first choice for the treatment of infants suffering from colic. Practically every part of the plant is edible. Fennel also helpful for protects the liver from toxins and has a slight pain reducing potential in dysmenorrhea or painful of menstrual cramps. For millennia, Fennel has been used as estrogenic agents. Specifically it has been reputed to increase milk secretion, promote menstruation, facilitate birth, alleviates the symptoms of the male climacteric and increase libido. In the 1930's, some interest was shown in this plant in the development of synthetic estrogens. The main constituent of the essential oils of fennel has been considered to be the active estrogenic agent. However, further research suggests that actual pharmacologically active agents are polymers of anethole, such as dianethole and photoanethole ${ }^{(14)}$. The other substances have been edentified in fennel including estragole, hydroxycinnamic acid derivatives, flavonoid, quercetin, kaempferol, chlorogenic acid, eriocitrin, rutin, miquelianin, rosmarinic acid and caffeoylquinic acid. Some of these substances in fennel have antioxidant activity too.

In age of 50, naturally women are starting to get irregularly menstrual cycles, pointed by no ovulation for several menstrual cycles. When the cycles were stopped, called menopause. In this phase, estrogen production decrease drastically, so cannot balance production of Follicle Stimulating Hormone (FSH) and Luteinizing Hormone (LH) to induce ovulation ${ }^{(8)}$. The fluctuating hormone levels that often occur during menopause cause some symptoms such as vasomotoric, physiologist and psychologist. The most occurrence symptom was hot flushes, and also any skin damage, negativity, anxiety, mood swings or vaginal dryness, hypercholesterolemia and osteoporosis ${ }^{(6)}$. Therapy to reduce menopausal symptoms by giving external estrogen, called Hormone Replacement Therapy (HRT), have so many unpleasant side effects such as breast pain, increase of weight body, headache, vaginal bleeding and increase risk of breast cancer. Concerning these unpleasant effects from taking HRT, especially for long time used and also costly, it is important to search another alternative using herbal medicine which have some criteria such as effective, natural, low toxic, save (especially for long term used) and suitable for menopause women. This alternative HRT is phytoestrogen, which easily can find in Indonesian medicinal herbs ${ }^{(6)}$.

In the aim of developing pharmaceutical dosage form phytopharmaca of phytoestrogen from Indonesian indigenous herbal medicine, it is important to do the clinical and preclinical trial. In preclinical trial, we have to do the efficacy through the animal experimental research. This paper describes the efficacy study of estrogenic effect from fennel fruit extract on immature, 19 days old, female rats' model, which represent the climacteric/menopause phase, where estrogen level is very low because ovary produces no estrogen ${ }^{(9)}$. Measured parameters were wet weight of uterine, proliferation of uterine, estrus cycles and vaginal lubrication. These data will inform us about preclinical estrogenic effect from fennel fruit extract, as scientific base to continuing clinical trial to get phytoestrogen for alternative HRT implementation.

\section{MATERIALS AND METHODS}

Extraction of Fennel Fruit Extract. Dried fennel fruit was obtained from Balai Penelitian Tanaman Obat (BPTO) Tawang mangu, Solo and determinated by Lembaga Herbarium Bogoriense LIPI, Bogor. Fennel fruit was macerated with distilled ethanol and then dried through vacuum rotary evaporator. The crude extract was stored in desiccators until constant weight. Sample were suspending with CMC Na $0.5 \%$

Preparing Immature Rats Model. Thirty female and fifteen male Sprague-Dawley rats, 4 months old, 150-200 g BW, were purchased from Pusat Penelitian \& Pengembangan Gizi, Faculty of Medicine, University of Indonesia, Jakarta. Animals were caged with five animals per cage, in a animal laboratory that is already set up for 12 hours light and 12 hours dark, enough good air flow and sanitary. After one week acclimatization, every two female rats were caged with one male rat. After 7 days, female rats were separated, one rat each, during gestation period (21 days). Every delivery date and litter size was recorded. In the age of 16 - 19 days old, vaginal smear was done to check the estrous cycles. Vaginal smear procedure was conducted by Martin, 1990 and Turner, 1971.

Experimental Protocol. Twenty five 19 days old female rats then were divided into five groups, namely normal group, estradiol $(0,9 \mu \mathrm{g} / 200 \mathrm{~g} \mathrm{BW})$ control group, and three level doses of fennel fruit extract. Each group was fed one of diets described in 
Table 1, per-oral by gavages into gastric, once a day for 16 days. At days 13 until 17, the vaginal smear was done again. At the days 17, blood samples were taken from all animals for hormone analysis and autopsy under anesthesia. Uterine organs were quickly removed, weighed and immersed in Bouin's solution. Histological preparation were done using paraffin method and stained with hematoxylin/eosin. Slides were examined under microscope and micro projector for analysis of the uterine, measure thickness of endometrium, diameter of uterine and endometrium.

Table 1. Groups of Animal Model during Treatment.

\begin{tabular}{clc}
\hline Groups & Treatment & $\mathrm{n}$ \\
\hline N & Normal group & 5 \\
KE & Estradiol control group & 5 \\
D1 & Extract $30 \mathrm{mg} / 200 \mathrm{gBW}$ & 5 \\
D2 & Extract $60 \mathrm{mg} / 200 \mathrm{gBW}$ & 5 \\
D3 & Extract $120 \mathrm{mg} / 200 \mathrm{gBW}$ & 5 \\
\hline
\end{tabular}

Vaginal Smear Assay(10). Vaginal smear preparation were done by smear the cotton bud that already wet with physiological $\mathrm{NaCl} 0.9 \%$ into rat vagina. The smears were fixed by placing the slide in methanol for 15 minutes, allowing it to dry and staining it with Giemsa solution for 15 minutes. The excess stain is washed off with tap water and the slide is dried. Slides were observed using microscope.

Statistical Analysis. All quantitative data were analyzed using computer programme, Statistical Product and Service Solution (SPSS) 11.5 for windows. Normality test with Kolmogorov-Smimov and homogenity test with Levene variance. ANAVA test continuing with LSD test. A p value below 0.05 was chosen as the limit of statistical significance ${ }^{(16)}$.

\section{RESULT AND DISCUSSION}

Samples was prepared by maseration fennel with ethanol $96 \%$ with shaking for $6 \times 1$ hour. Macerate was evaporate on $40{ }^{\circ} \mathrm{C}$ by Rotaryevaporator. The yield of extract was $25 \mathrm{~g}$ from $500 \mathrm{~g}$ dried Fennel Fruit. This experiment used 19 days old immature rat model. According to the biological data, on the age of 19 days, rat can be separated from its mother and have no estrous cycles yet. Generally, female rat can be mated with the male in 10 weeks old ${ }^{(15)}$. This model can represent the climacteric/menopause phase, where estrogen level is very low because ovary produces no estrogen.
Before treatment, the vaginal smear assay were done to convince that at 19 days old, rat have no estrous cycles yet. Vaginal smears assay also done after treatment in all groups to investigate its effect on vaginal dryness. This assay is based on the fact that rat exhibit a cyclical ovulation with associated changes in vaginal cytology. The effect of quantitative changes in the secretion of hormones on the vagina can observe by taking a series of vaginal smears and examining these for cornified cells, leukocytes and epithelial cells. A positive estrous smear is one in which only large, irregular cornified cells are seen, indicating maximum growth of the vaginal mucosa. A metestrus smear will have many cornified cells, but also some leukocytes and epithelial cells, indicating the postovulatory stage and desquamation of the vaginal mucosa. A diestrus smear will show few epithelial cells, mucus, and few leukocytes, indicating a quiescent uterus and resting vaginal epithelium. A proestrus smear will have many epithelial cells with granular cytoplasm, indicating a rapidly growing vaginal epithelium and the preovulatory stage ${ }^{(17)}$. This assay showed that Fennel fruit extract have estrogenic effect on vagina. Surprisingly, at $60 \mathrm{mg} / 200 \mathrm{~g} \mathrm{BW}$, it can induce estrous cycle on immature rat and at $120 \mathrm{mg} / 200 \mathrm{~g} \mathrm{BW}$ it can induce vaginal lubrication.

\begin{tabular}{|c|c|c|c|c|c|c|c|c|c|c|c|c|c|c|}
\hline \multirow{2}{*}{ Group } & \multicolumn{2}{|c|}{$\begin{array}{c}\text { Day } \\
13\end{array}$} & \multicolumn{4}{|c|}{$\begin{array}{c}\text { Day } \\
14\end{array}$} & \multicolumn{3}{|c|}{$\begin{array}{c}\text { Day } \\
15\end{array}$} & \multicolumn{3}{|c|}{$\begin{array}{c}\text { Day } \\
16\end{array}$} & \multirow{2}{*}{$\begin{array}{l}\text { Vaginal } \\
\text { Lubri- } \\
\text { cation }\end{array}$} & \multirow{2}{*}{$\begin{array}{l}\text { Estrous } \\
\text { cycle }\end{array}$} \\
\hline & c & $\mathrm{L}$ & $E$ & C & $\mathrm{L}$ & $E$ & c & $\mathrm{L}$ & $E$ & C & $\mathrm{L}$ & $E$ & & \\
\hline \multirow{4}{*}{ Normal } & - & ++ & + & - & ++ & +++ & - & ++ & + & - & +++ & ++ & & \\
\hline & - & $\begin{array}{l}+ \\
+\end{array}$ & $\begin{array}{l}+ \\
+\end{array}$ & - & $\begin{array}{l}+ \\
+ \\
+\end{array}$ & $\begin{array}{ll}+++ \\
++\end{array}$ & - & $\begin{array}{c}+ \\
++ \\
++\end{array}$ & $\begin{array}{l}+ \\
+\end{array}$ & : & $\begin{array}{l}++ \\
+\end{array}$ & $\begin{array}{l}+ \\
+\end{array}$ & & \\
\hline & - & + & + & - & + & ++ & - & + & ++ & - & ++ & ++ & & \\
\hline & + & + & $\begin{array}{l}+ \\
+\end{array}$ & it & $\begin{array}{l}+ \\
+ \\
+\end{array}$ & $\begin{array}{l}++ \\
+ \\
+\end{array}$ & ++ & $\begin{array}{l}++ \\
++\end{array}$ & $\begin{array}{l}++ \\
++ \\
++\end{array}$ & $\therefore$ & & & & \\
\hline \multirow{4}{*}{ Estradiol } & +++ & + & + & + & + & + & +++ & + & + & ++ & ++ & + & & \\
\hline & ++ & + & † & + & + & + & ++ & ++ & ++ & ++ & + & + & $\checkmark$ & $\checkmark$ \\
\hline & ++ & + & + & + & + & + & +++ & ++ & + & + & ++ & ++ & & \\
\hline & - & +++ & + & - & ++ & ++ & - & ++ & +++ & - & ++ & ++ & & \\
\hline Dose I & - & ++ & + & - & ++ & ++ & - & + & +++ & - & ++ & ++ & & \\
\hline & - & +++ & + & - & ++ & + & - & ++ & + & + & +++ & ++ & - & - \\
\hline \multirow{2}{*}{ BW } & : & $\begin{array}{l}++ \\
++ \\
++\end{array}$ & $\begin{array}{l}+ \\
+\end{array}$ & $\begin{array}{l}+ \\
-\end{array}$ & $\begin{array}{l}++ \\
++ \\
++\end{array}$ & $\begin{array}{c}+ \\
++ \\
+\end{array}$ & $\begin{array}{l}+ \\
-\end{array}$ & $\begin{array}{ll}++ \\
++ \\
++\end{array}$ & $\begin{array}{l}+++ \\
++ \\
++\end{array}$ & - & $\begin{array}{l}++ \\
+++\end{array}$ & $\begin{array}{l}++ \\
++ \\
++\end{array}$ & & \\
\hline & ++ & t+ & + & + & + & + & + & ++ & + & + & +++ & + & & \\
\hline Dose II & + & + & + & + & ++ & + & ++ & +++ & +++ & ++ & ++ & ++ & & \\
\hline \multirow{3}{*}{ BW } & + & ++ & + & + & + & + & + & + & + & + & ++ & + & - & $\checkmark$ \\
\hline & + & $\begin{array}{l}++ \\
+\end{array}$ & $\begin{array}{l}+ \\
+\end{array}$ & $\begin{array}{l}+ \\
+\end{array}$ & $\begin{array}{l}+ \\
+ \\
+\end{array}$ & $\begin{array}{l}++ \\
++ \\
++\end{array}$ & $\begin{array}{l}++ \\
+ \\
+\end{array}$ & $\begin{aligned}++ \\
+\end{aligned}$ & $\begin{array}{l}++ \\
++\end{array}$ & $\begin{array}{l}++ \\
+ \\
+\end{array}$ & $\begin{array}{c}+ \\
++\end{array}$ & $\begin{array}{lll}+++ \\
++\end{array}$ & & \\
\hline & +++ & ++ & + & + & ++ & + & + & + & ++ & ++ & +++ & ++ & & \\
\hline Dose III & ++ & ++ & + & + & ++ & t+ & +++ & ++ & t+ & ++ & ++ & +++ & & \\
\hline $120 \mathrm{mg} / 200 \mathrm{~g}$ & $\begin{array}{l}+++ \\
+++\end{array}$ & $\begin{array}{l}++ \\
++ \\
++\end{array}$ & $\begin{array}{l}+ \\
+\end{array}$ & $\begin{array}{c}+ \\
+\end{array}$ & $\begin{array}{l}++ \\
++ \\
++\end{array}$ & $\begin{array}{ll}++ \\
+++ \\
++\end{array}$ & $\begin{array}{l}+ \\
+\end{array}$ & $\begin{array}{l}+++ \\
++\end{array}$ & $\begin{array}{l}+ \\
+\end{array}$ & $\begin{array}{cc}+ \\
++\end{array}$ & $\begin{array}{l}++ \\
++\end{array}$ & $\begin{array}{ll}+ \\
++\end{array}$ & $\sqrt{ }$ & $\sqrt{ }$ \\
\hline & $\begin{array}{l}+++ \\
++\end{array}$ & $\begin{array}{l}++ \\
++\end{array}$ & $\begin{array}{l}+ \\
+\end{array}$ & $\begin{array}{l}+ \\
+ \\
+\end{array}$ & $\begin{array}{l}++ \\
++ \\
++\end{array}$ & + & $\begin{array}{l}+ \\
++\end{array}$ & $\begin{array}{l}++ \\
++\end{array}$ & $\begin{array}{l}+ \\
++\end{array}$ & $\begin{array}{ll}++ \\
++ \\
++\end{array}$ & $\begin{array}{l}t++ \\
+t+\end{array}$ & $\begin{array}{l}+++ \\
++4 \\
4\end{array}$ & & \\
\hline
\end{tabular}

Note: $\mathrm{C}=$ Cornified Cell; $\mathrm{L}=$ Leucocyte Cell; $\mathrm{E}=$ Epithelial Cell $(+)=$ less $;(++)=$ moderate $;(+++)=$ many; $(-)=$ none $; \sqrt{ }=$ positif

The summary is shown at Table 3 . This effect can help vaginal dryness in menopausal symptom 
Table 3. Vaginal Smears Analysis Four Days before Treatment (D0) and Four Days after Treatment (D16).

\begin{tabular}{|c|c|c|c|c|c|}
\hline & \multirow{2}{*}{$\begin{array}{c}\text { Groups of immature Rat } \\
\text { (19 days old) }\end{array}$} & \multicolumn{2}{|c|}{$\begin{array}{l}\text { Vaginal } \\
\text { Lubrication }\end{array}$} & \multicolumn{2}{|c|}{ Estrous Cycle } \\
\hline & & Do & D16 & DO & D16 \\
\hline$N$ & $=$ Normal Immature Rat & $\cdot$ & $\cdot$ & $\cdot$ & $\cdot$ \\
\hline KE & $=$ Estradiol $0.9 \mu \mathrm{g} / 200 \mathrm{gBB}$ & $\cdot$ & $\sqrt{ }$ & $\cdot$ & $\sqrt{ }$ \\
\hline D1 & $1=$ Extract Dose $30 \mathrm{mg} / 200 \mathrm{gBW}$ & $\cdot$ & $\cdot$ & $\cdot$ & $\cdot$ \\
\hline D2 & $2=$ Extract Dose $60 \mathrm{mg} / 200 \mathrm{gBW}$ & $\cdot$ & - & $\cdot$ & $\sqrt{ }$ \\
\hline D3 & $3=$ Extract Dose $120 \mathrm{mg} / 200 \mathrm{gBW}$ & $\cdot$ & $\sqrt{ }$ & $\cdot$ & $\sqrt{ }$ \\
\hline
\end{tabular}

Another parameters investigated is wet weight of uterine, the common parameter in estrogenic activity study. In this study, fennel fruits extract start at 60 $\mathrm{mg} / 200 \mathrm{~g} \mathrm{BW}$ also increased wet weight uterine of immature rat significantly $(\alpha=0.05)$ compared with normal immature rats group. Increasing doses showed the increasing of wet weight uterine. Picture 1 showed data of wet weight uterine from all groups after treatment with fennel fruit extract for 16 days. Blood collecting and autopsied were done four hours after last treatment. Uterine were weighed immediately after autopsied. At Figure 1, also showed the effect of fennel extract on the size and length of uterine.

In woman physiological body, one of estrogenic activity is having proliferation effect on uterine. Estrogen can induce water intake of uterine. In previous study, we found that fennel fruit extract also can increase estradiol plasma level on immature rat significantly $(\alpha=0.05)$ comparing with normal immature rat ${ }^{(1)}$. So it showed also the correlation in this study that fennel extract also can give proliferation effect on uterine.
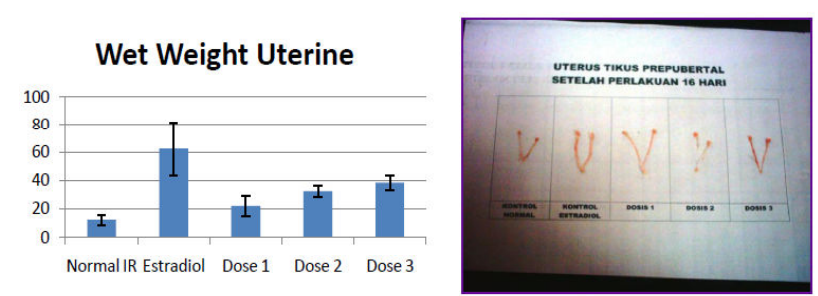

Figure 1. Wet Weight Uterine from All Groups after Treatment with Fennel Fruit Extract for 16 days.

In other way, in utherothropic bioassay, phytoestrogen, a weak agonist for estrogen receptor, can cause uterine proliferation significantly. Further investigation was done by histological analysis using haematoxillin eosin staining. The diameter of uterine and thickness of endometrium were measured under slide microprojector. The results can be seen in Figure 2. Histological data also obtained increase of all the histological parameter for uterine. Start at $60 \mathrm{mg} / \mathrm{kg}$ BW, fennel extract significantly $(\alpha=0.05)$ increase the growth of uterine comparing with normal immature group. Increasing doses also produce increasing diameter of uterine and thickness of endometrium.
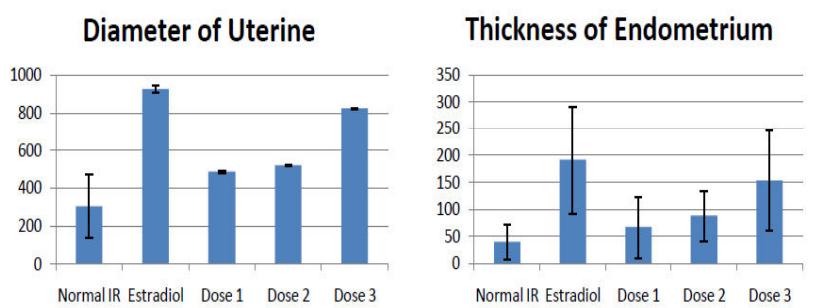

Figure 2. Diameter of Uterine and Thickness of Endometrium from All Groups after Treatment with Fennel Fruit Extract for 16 Days.
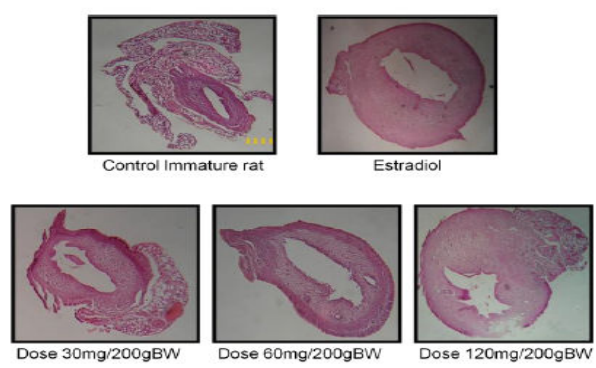

Figure 3. Histological Preparation of Uterine after Treatment with Fennel Fruit Extract for 16 Days.

\section{CONCLUSION}

This study showed that fennel extract have estrogenic activity. Start on $60 \mathrm{mg} / 200 \mathrm{~g} \mathrm{BW}$, fennel extract significantly ( $\alpha=0.05)$ increasing wet weight uterine, lengthen the uterine and increasing proliferation of uterine, such as uterine diameters, endometrium diameters and uterine thickness. Fennel extract also showed vaginal lubrication effect, surprisingly start on $60 \mathrm{mg} / 200 \mathrm{~g} \mathrm{BW}$ could induce estrous cycle.

\section{REFERENCES}

1. Agustini, Kurnia. Yosep Saepudin. 2006. Pengaruh pemberian ekstrak buah adas (Foeniculum vulgare Mill.) terhadap kadar hormone estradiol dan FSH plasma tikus putih betina galur Wistar yang diovariektomi. Majalah Ilmiah Artocarpus, Media Pharmaceutica indonesiana, Vol.6, No.2.

2. Agustini, Kurnia, Sumali Wiryowidagdo, Dadang Kusmana. 2005. Efek estrogenic biji klabet (Trigonella foenum graecum L.) terhadap perkembangan uterus tikus putih betina. Jurnal Bahan Alam Indonesia, Vol.4, No.2.

3. Anonim.1979. Materia Medika Indonesia. Jilid III. 
Departemen Kesehatan RI, Jakarta: xviii +196 hlm.

4. Anonim. 2000. Parameter Standar Umum Ekstrak Tumbuhan Obat. BPOM Departemen Kesehatan RI, Jakarta: viii $+68 \mathrm{hlm}$.

5. A.V. Nalbandov. 1990. Fisiologi Reproduksi Pada Mamalia dan Unggas. Jakarta: Penerbit Universitas Indonesia.

6. Badziad, Ali. 2003. Endokrinologi Ginekologi. Jakarta: Media Aesculapius. Fakultas Kedokteran Universitas Indonesia, Jakarta: xxiv $+167 \mathrm{hlm}$

7. diFiore, Mariano SH. 1986. Atlas Histologi Manusia. Edisi kelima. Terj. dari Atlas of Human Histology, oleh Moch. Martoprawiro, dkk. EGC, Jakarta : 220-245.

8. Guyton, C.Arthur. 1995. Fisiologi manusia dan mekanisme penyakit. Terj. dari Human Physiology and mechanism of disease, oleh Petrus Andrianto. EGC, Jakarta: xii +821 hlm.

9. Kanno, J.L. Onyon, J. Haseman \& P. Fenner-Crisp, J. Ashby, \& W. Owens. 2001. The OECD Program to Validate Rat Uterothrophic Bioassay to Screen Compounds for in Vivo Estrogenic Responses : Phase 1. Enviromental Health Perspectives. Vol.109. No.8: 785-94.

10. Martin, Annamarie, A.S. Bingel \& D.P. Waller. 1990. Bioscreening Technique for Antifertility Activity. Dalam: Thompson, Emmanuel B. Drug Bioscreening, Drug Evaluation Techniques in Pharmacology. VCH Publishers, New York: xvii $+288 \mathrm{hlm}$.

11. Mills, Simon \& K. Bone. 2000. Principles and Practice of Phytoterapy. Modern Herbal Medicine. Churcill Livingstone, Edinburgh: $\mathrm{xx}+643 \mathrm{hlm}$.

12. Owens, William, J. Ashby, J. Odum \& L. Onyon. 2003 The OECD Program to Validate the Rat Uterotrophic Bioassay. Phase 2: Dietary Phytoestrogen Analyses. Enviromental Health Perspectives. Vol.111. No.12: 1559-1567.

13. Partodihardjo, Soebadi. 1992. Ilmu Reproduksi Hewan. Mutiara Sumber Widya, Jakarta: xvi +588 hlm.

14. Puleo, Michael Albert. 1980. Fennel and anise as estrogenic agents. Journal of Ethnopharmacology. Vol.2:337-244.

15. Smith, J.B. \& S. Mangkoewidjojo. 1988. Pemeliharaan, Pembiakan dan Penggunaan Hewan Percobaan di Daerah Tropis. Penerbit Universitas Indonesia, Jakarta: 37-55.

16. Sulaiman, W. 2003. Statistik Non-parametrik: Contoh Kasus dan Pemecahannya dengan SPSS. Penerbit Andi, Yogyakarta: vi $+168 \mathrm{hlm}$

17. Turner, A Robert \& P. Hebborn. 1971. Screening Methods in Pharmacology. Volume II. Academic Press, New York: xvii +288 hlm. 